\title{
IMPACT OF POPULATION MIGRATION IN TESSO NILO NATIONAL PARK RIAU PROVINCE
}

\section{Harapan Tua RFS and Mimin Sundari Nasution}

Lecturer of Public Administration Faculty Social Science and Political Science University of Riau Email: harapan.tua@lecturer.unri.ac.id,mimin.sundari@lecturer.unri.ac.id

\begin{abstract}
The Tesso Nilo National Park is a conservation area that should be free from settlements and plantations. The migrants who come to the TNTN area are generally tough farmers who come from various ethnic groups such as Javanese, Batak, Palembang, even now there are Toro Bali. This study aims to look at Population Migration in Toro Jaya Hamlet, in the TNTN Area and the Impact of Population Migration on Forest Damage in the TNTN Area. This research uses a qualitative approach. Key Research Informants were selected by purposive and then using the snow ball sampling technique to determine the next informant. The method of data collection was done by means of in-depth interviews, focus group discussions, documentation. Then the data is analyzed based on the Interactive analysis model. The results show that population migration in TNTN has increased significantly coupled with the birth rate of the population, which on average are couples of productive age, which has made fertile land for population growth in TNTN. The smooth accessibility with the entry of public transportation vehicles (buses) to TNTN, especially Dusun Toro Jaya, coupled with the production of their "oil palm" plantation crops have also become a pull factor for many people to migrate to TNTN. This migration of the population has resulted in forest encroachment into residential areas and oil palm and rubber plantations. The encroachment will have an impact on the destruction and loss of native forest from Tesso Nilo National Park.
\end{abstract}

Keywords: Population; migration; forest destruction

\section{DAMPAK MIGRASI PENDUDUK DI TAMAN NASIONAL TESSO NILO PROVINSI RIAU}

\begin{abstract}
ABSTRAK. Taman Nasional Tesso Nilo merupakan kawasan konservasi yang seharusnya bebas dari pemukiman dan perkebunan permasalahan pertambahan penduduk yang tidak terkendali akibatnya mudah bagi "migrasi masuk" ke lokasi TNTN dan memberikan dampak kerusakan hutan menjadi semakin parah. Para migran yang datang ke kawasan TNTN tersebut pada umumnya adalah petani tangguh yang berasal dari berbagai suku bangsa seperti Jawa, Batak, Palembang, bahkan sekarang ada Toro Bali. Penelitian ini bertujuan untuk melihat Migrasi Penduduk di Dusun Toro Jaya, di Kawasan TNTN serta Dampak Migrasi Penduduk Terhadap Kerusakan Hutan di Kawasan TNTN. Penelitian ini mengunakan pendekatan kualitatif. Lokasi penelitian adalah kawasan hutan Taman Nasional Tesso Nilo yang telah menjadi perkampungan (pemukiman) penduduk.Key Informan Penelitian dipilih dengan menetapkan (purposive) kemudian menggunakan teknik snow ball sampling untuk penentuan informan selanjutnya. Metode pengumpulan data dilakukan dengan cara wawancara mendalam (indepth interview), kelompok diskusi terarah (focus group discussion), dokumentasi. Kemudian data dianalisis berdasarkan model analisis Interactive.Hasil menunjukkan bahwa migrasi penduduk di TNTN meningkat secara signifikan ditambah dengan tingkat kelahiran penduduk yang rata-rata adalah pasangan usia produktif telah menjadikan tanah yang subur bagi pertumbuhan penduduk di TNTN. Aksesibilitas yang lancar dengan masuknya kendaraan umum pengangkut orang (Bus) ke TNTN khususnya Dusun Toro Jaya ditambah dengan telah berproduksinya tanaman perkebunan sawit mereka juga menjadi faktor penarik bagi banyak orang untuk bermigrasi ke TNTN. Migrasi penduduk tersebut mengakibatkan terjadinya perambahan hutan menjadi areal pemukiman dan perkebunan kelapa sawit dan karet. Perambahan tersebut akan berdampak pada rusak dan hilangnya hutan asli dari Taman Nasional Tesso Nilo.
\end{abstract}

Kata kunci: Penduduk; Migrasi; Kerusakan hutan

\section{INTRODUCTION}

Human survival depends on human ability to maintain the sustainability of their ecosystem, so humans must always maintain a harmonious relationship with their environment (Dugang, 2013). A worrying symptom at this time is that there has been uncontrolled population growth due to both fertility and population migration. This uncontrolled population growth resulted in tremendous pressure on natural resources and the environment. The pressure on natural resources and the environment that is currently occurring in almost all parts of Indonesia, even the pressure on land needs settlements, agriculture, plantations. resulted in a decrease in area forest.

Nature Conservation Forest Area is an area with certain characteristics, both on land and in waters that has the function of protecting life support systems, preserving the diversity of plant and animal species, as well as the sustainable use of biological natural resources and their ecosystems (Danusaputra, 1980).

Forest damage is caused by population growth either around the forest or outside the forest, which becomes more widespread when the owners of becomes more

DOI: 10.24198/sosiohumaniora v23i1.30700

Submited: 21 November 2020, Accepted: 17 December 2020, Publish: 08 March 2021 
capital companies, cukong, officials, foundations, cooperatives and so on enter. The strength of capital and technology makes it easier for forest function changes to occur. According to Vinod (2002), population growth has been blamed for poverty and environmental degradation so that rapid population growth or illegal migration will lead to natural disasters, hunger, depletion of natural resources, environmental and ecological damage.

Likewise with the Riau Tesso Nilo National Park (TNTN) Forest area, which the government has designated as an area for nature conservation, through "Decree of the Minister of Forestry Number 255 / Menhut-II / 2004 and Decree of the Minister of Forestry Number 663 / MENHUT-II / 2009". Tesso Nilo forest area with an area of 167,618 ha.The location of Tesso Nilo National Park is in: Pelalawan Regency, Indragiri Hulu Regency, Kuantan Singingi Regency, and Kampar Regency, with 0.50 'South Latitude and 102.38' East Longitude.

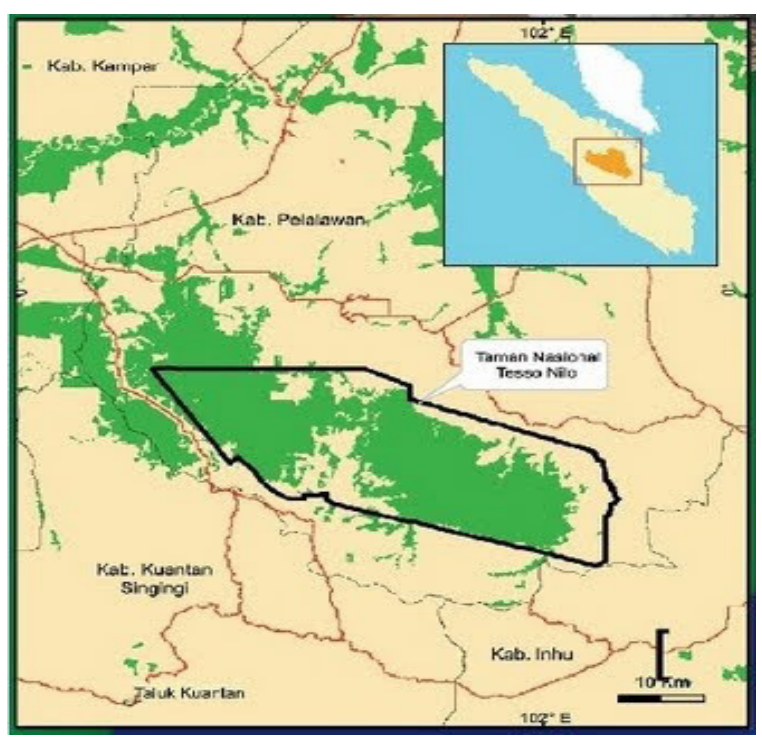

Source:www.wwf.or.id

Figure 1. Location Map of the TNTN Area

Without realizing it, uncontrolled forest exploitation and encroachment has caused environmental imbalance in the TNTN area. The habitats of elephants and tigers are disturbed and it is not uncommon for herds of elephants to come to destroy the oil palm and rubber plantations of the residents and even herds of elephants are found entering residential areas and destroying houses of residents in the TNNP area. During 2012, WWF Riau recorded that 12 elephants died as a result of the conflict and were eventually poisoned. Meanwhile, tigers, bears and other animals are often caught in traps snares.

In 2006, the Minister of Forestry issued a Ministerial Regulation which established Riau Province as the center for Sumatran elephant conser- vation (Hakim, 2005). Through this Ministerial Regulation, it is hoped that it can answer the problem of human-elephant conflict in Riau. However, the reality on the ground is that TNTN, which is expected to be one of the solutions in handling human-elephant conflict, is not yet free from various problems that threaten the integrity of the area, particularly as elephant habitat.Types of protected animals at TNTN.

The Minister of Forestry issued a Ministerial Regulation that established Riau Province as the center for Sumatran elephant conservation (Miles, 1994). Through this Ministerial Regulation it is hoped that it can answer the problem of humanelephant conflict in Riau. However, the reality on the ground is that TNTN, which is expected to be one of the solutions for handling human-elephant conflict, is not yet free from various problems that threaten the integrity of the area, especially as elephant habitat. Types of protected animals at TNTN :

1. Sumatran tiger (Panthera tigris sumatrae)

2. Sumatran Elephant(Elephas Maximus Sumatranus)

3. Pangolin (Sweet Javanicu)

4. Deer (Cervus Timorencis)

5. Forest Ape (Macacca Fascicilarus)

In the year ofln 2010, the population of Riau was 5,543,031 people, where the population growth of Riau was in the high category, namely 4.46 percent, far above the national standard of 1.3 percent, so that Riau became the 10th largest population province in Indonesia. Population growth in Riau is due to high fertility rates and high in-migration. The high rate of in-migration to Riau province shows that Riau is seen as an area that has rich natural resources coupled with the available accessibility.

However, population growth also brings other problems to the environment, population growth requires various other living facilities, land for settlements, agriculture, plantations and so on, resulting in the destruction of forests to be used both as a source of life and an economic source for their survival.

Forest damage in the TNTN forest area is related to a very significant population increase around the TNTN area. Uncontrolled population growth due to easy access to "in-migration" to the TNTN location has resulted in increasingly severe forest destruction. The data shows that the population growth in the TNTN area is as follows:According to the results of investigations by Balai TNTN and WWF Riau, around 2,279 heads of households have settled in the TNTN area: 2,176 (95 percent) of families are migrants from outside the village around TNTN and only 103 families (5\%) of the community around the 
TNTN area. Encroachment is increasingly rampant, until 2009 there were 14 loci of encroachment, spreading along the corridors and village centers. Its area reaches $28,606.08$, or $34.5 \%$ of the TNTN area. The four largest loci are the PT RAPP Ukui - Gondai Corridor (8,242.34 ha), Kuala Onangan Toro Jaya (7,769.27 ha), Bagan Limau (3,852.21 ha), and Toro Makmur (2,440 ha).

Of course these conditions are different today, ksurveillance of Teso Nilo National Park (TNTN), is no longer what it used to be. Forests that are so dense and beautiful with their animals, it's hard to find them in this area.Moreover, in an area a few kilometers into the TNTN, to be precise in the areas of Toro Jaya, Toro Makmur, Toro Regar, Toro Palembang, Toro Bali and Toro Ujung have become areas of oil palm, rubber and residential areas. This area has been opened since 2003. And currently it is estimated that there are around 6,000 to 7,000 families (heads of families), besides that there are even elementary and junior high schools and several houses of worship such as a mosque, mosque, church, and so on.

Migration (movement) is the movement of a population with the aim of settling from one place to another beyond political / state boundaries or administrative boundaries / boundaries within a country (Vinod, 2002). In general, the number of people who come and go between countries is comparable. The regulations or laws made by many countries are generally very difficult and strict for a person to become a citizen or reside permanently in another country.

In line with current regional autonomy, the policy on population migration to enter certain regions / cities has also become increasingly limited. Autonomous regions have provided many requirements for a resident to be able to enter the destination area / city. Limited access to migrate makes population movement narrower and more difficult. Access to migration only belongs to people who have skills and capital, while those who do not have the skills and capital will find it difficult to carry out migration both to cities and other destinations.

Population growth is the change in population in a certain area at a certain time compared to the previous time (Badan Pusat Statistik). Population growth is a dynamic balance between forces that reduce population size. The population will continuously be affected by the number of babies born (increasing the number of population), but at the same time it will also be reduced by the number of deaths that occur in all age groups. Meanwhile, migration also plays a role in increasing and decreasing population (Ida Bagus Mantra, 2009).

Population migration that occurred in Indonesia during the New Order era was very well known as the term "transmigration", which is the movement of population from densely populated areas to areas that are sparsely populated. This concept became a very successful program in that era, but after the reformation, the transmigration policy experienced a decline or even dimmed as a program for the welfare of people who do not have land or a proper place to live due to natural disasters and so on.

The movement of the population by bringing their customs and culture to their destination is a powerful strategy for the success of the transmigration program, in addition to the many assistance and facilities provided by the State so that they are successful in their destination, including food rations, housing, housing land, agricultural land, fertilizers, transportation to the destination area, life insurance for 2 (two) years and health insurance as well as counseling from agricultural extension workers.

For Naim (2013), the term migration for the Minangkabau tribe is often referred to as "Merantau", where the meaning of migrating as suggested by the Minangkabau tribe in the West Sumatra area may be different from migration carried out by other tribes, but wandering also means leaving the village. page to the area of people who are far from sight. Migrating is done because of many factors, both to fix economic problems and to pursue knowledge (education), all of which become motives that determine the direction of the destination of the area of interest whose purpose is to change the way of life of a person or group of people.

Not only the Minangkabau, but the Batak, Javanese, Bugis, Flores, Ambon and many other ethnic groups in Indonesia who have a migratory culture (migration). Migration from a sociological concept according to Nain (2013) contains meanings:

1. Leaving your hometown;

2. By "will of their own accord";

3. For long numbers of time or not;

4. With the aim of seeking a living, seeking knowledge or seeking experience;

5. Usually with the intention of returning home and;

6. Wander is an institutionalized social institution (Naim, 2013; 3).

Meanwhile the factors that influence the occurrence of migration are the social and economic conditions of the area, inward migration because it changes the welfare for the better and the availability of adequate means of mobility(Trendyari \& Yasa, 2014).

Brinley Thomas in Naim (2013) emphasizes that migration is seen as a movement of movement 
(including the movement of permanent residence from one country to another) because of the "own will" of the person concerned, both individually and in groups.

Meanwhile according to Noris (1972) there are 3 components that underlie it, the first is Remigration, the second is the opportunity and the third is force migration, which of these three components will be seen which are the most relevant to the people of the Tesso Nillo National Park area.

Several previous studies have explained that (Wilonoyudho, 2010)Population growth, migration and environmental quality are influenced by human behavior that has not been able to adapt so that environmental pollution such as cutting trees, disposing of waste becomes normal behavior, while (Ita et al., 2014)on the impact of migration on growth economy and poverty will experience environmental degradation.

From this concept, it turns out that there is a difference between "merantau" (migration) carried out by a person or group of people with the "Transmigration" program, namely transmigration on a voluntary basis, meaning that population movements that were confirmed through government programs in the New Order were not the same as the term "merantau" according to Naim. (2013), because wandering must come from their own will (volition).

Based on these conditions, the authors conducted scientific research aimed at finding out how population migration in Toro Jaya hamlet, in the TNTN area and the impact of population migration on forest damage in the TNTN area?

\section{METHODS}

This research uses a qualitative approach. By using this approach, it is expected that data relating to population growth, especially those related to motivation to migrate, survival strategies and perceptions of the environment. The research location is the forest area of Tesso Nilo National Park which has become a residential area, Dusun Kuala Kolam, Toro Jaya, Toro Doli, Toro Makmur, Toro Regar, Toro Bali, and Toro Ujung in Lubuk Kembang. Bunga Village, Ukui, Pelalawan Regency, Riau Province. Key Informants This study was selected by determining (purposive) community leaders, NGOs, Tesso Nilo National Park Office, Pelalawan, and residents in residential areas, subsequently using purposive sampling technique to determine the next informant.

Methods of data carried out by in-depth interviews, focus group discussions, documentation. Then the data is based on an Interactive analysis model.

\section{RESULTS AND DISCUSSION}

\section{Population Migration}

The migration of people to Toro Jaya occurred before the area managed by the HPH company PT Hutani Sola Lestari (HSL) and PT Siak Raya Timber (SRT) was designated by the government as a TNTN area. However, the migration that occurred was still limited to the need for labor by the two companies at that time. The process of determining the TNTN area was very slow compared to the rate of migration of residents to the surrounding Toro Jaya which is the heart of TNTN itself. The establishment of the new TNTN was in 2004, while the community who managed the Toro Jaya land existed in 2002-2003, even in Kuala Onangan Hamlet long before it was a residential area and according to local residents it was the initial "village" in the area.

The first wave of migration started with HPH workers from the two companies who were reluctant to leave the location after the government decided not to extend the concession period of the two companies (HSL and SRT), the workers had planted part of the $\mathrm{HPH}$ area as a place for farming and gardening at that time, as well as the Malay community. (original) who has also been living in that location for a long time. And after the HPH companies both HSL and SRT left the location, a second, third wave and so on entered the ex-PT location. HPH HSL and SRT which were later designated as TNTN areas.

The above events are in line with the HariisTodaro migration model, according to (Santoso, 2018)the industrial sector built in a rural environment will make the attractiveness of migration higher and this model predicts migration continues to flow from rural areas to urban areas or vice versa to the point where wages the minimum expected in urban areas is equivalent to actual attainable income in the rural sector.

The migrants who come to the TNTN area are generally tough farmers who come from various ethnic groups such as Javanese, Batak, Palembang, and even now there is Toro Bali. The giving of these names appears along with the tribes or clans who open land in the area the. The migrants understand and understand very well the techniques and characteristics of oil palm planting. In the end, most of the areas managed by migrant communities are clearing land for oil palm plantations and only a few plant rubber and other types of crops.

With the increasing population growth that makes residents look for new land to live in both as a place to live and also a place to make a living, many new settlers open land in the Tesso Nilo National 
Park area without permission from the government, even though the Tesso Nilo National Park area is not They are allowed to open settlements and also open plantation areas which currently have a lot of oil palm plantations in the area.

The following is the distribution of settlements around the Tesso Nilo National Park area

Table 1. Data on the Number of Villages around the TNTN Area

\begin{tabular}{|c|c|c|}
\hline districts & districts & Village \\
\hline \multirow[t]{5}{*}{ Pelalawan } & Style & Gondai Base \\
\hline & & Segati \\
\hline & Drain Base & Kesuma / Sei. Medang \\
\hline & Ukui & Lubuk Kembang Bunga \\
\hline & & Black Water \\
\hline \multirow{4}{*}{$\begin{array}{l}\text { Indragiri } \\
\text { Hilir }\end{array}$} & Turtle Sand & Pontian Mekar \\
\hline & & Lake Juang \\
\hline & & Sei. Rice-Rice \\
\hline & Glance & Water \\
\hline \multirow[t]{4}{*}{ Kampar } & Kampar left & Gunung sari \\
\hline & & Like Prosperous \\
\hline & & Mount Sahilan \\
\hline & Lower Left Kampar & Rantau Kasih \\
\hline \multirow{9}{*}{$\begin{array}{l}\text { Kuantan } \\
\text { Sengingi }\end{array}$} & Kuantan Hilir & Mount Melintang \\
\hline & Logas Tanag Datar & Situgal \\
\hline & & Encroachment \\
\hline & & Broad Stop \\
\hline & & Giri Sako \\
\hline & & Lubuk Kebun \\
\hline & & Upstream Tesso \\
\hline & & Logas Tanah Datar \\
\hline & Sengingi Hilir & Like Forward \\
\hline
\end{tabular}

Source: WWF, 2018

According to data from the Central Statistics Agency (BPS), the 22 villages have the following population:

Table 2, Number of Villagers in the vicinity of the TNTN Area

\begin{tabular}{lllr}
\hline districts & districts & \multicolumn{1}{c}{ Village } & $\begin{array}{c}\text { Total } \\
\text { population }\end{array}$ \\
\hline Pelalawan & Style & Gondai Base & 2,114 \\
& & Segati & 1,918 \\
& Drain Base & Kesuma / Sei. & 1,515 \\
& \multirow{2}{*}{ Ukui } & Medang & \\
& & Lubuk Kembang & 1,792 \\
& & Bunga & 2,022 \\
\hline
\end{tabular}

\begin{tabular}{|c|c|c|c|}
\hline \multirow{4}{*}{$\begin{array}{l}\text { Indragiri } \\
\text { Hilir }\end{array}$} & \multirow[t]{3}{*}{ Turtle Sand } & Pontian Mekar & 1,796 \\
\hline & & Lake Juang & 1,239 \\
\hline & & Sei. Rice-Rice & 1,633 \\
\hline & Glance & Water & 3,963 \\
\hline \multirow[t]{4}{*}{ Kampar } & \multirow[t]{3}{*}{ Kampar left } & Gunung sari & 3,977 \\
\hline & & Like Prosperous & 2,851 \\
\hline & & Mount Sahilan & 1,569 \\
\hline & $\begin{array}{l}\text { Lower Left } \\
\text { Kampar }\end{array}$ & Rantau Kasih & 596 \\
\hline \multirow[t]{10}{*}{$\begin{array}{l}\text { Kuantan } \\
\text { Sengingi }\end{array}$} & $\begin{array}{l}\text { Kuantan } \\
\text { Hilir }\end{array}$ & Mount Melintang & 2,260 \\
\hline & \multirow{7}{*}{$\begin{array}{l}\text { Logas } \\
\text { Tanag Datar }\end{array}$} & Situgal & 215 \\
\hline & & Encroachment & 687 \\
\hline & & Broad Stop & 2,056 \\
\hline & & Giri Sako & 1,921 \\
\hline & & Lubuk Kebun & 364 \\
\hline & & Upstream Tesso & 1,284 \\
\hline & & Logas Tanag Datar & 569 \\
\hline & $\begin{array}{l}\text { Sengingi } \\
\text { Hilir }\end{array}$ & Like Forward & 4,450 \\
\hline & \multicolumn{2}{|c|}{ Total } & 41,181 \\
\hline
\end{tabular}

Based on the table above, it can be concluded that there are approximately 41,181 inhabitants who live around the Tesso Nilo National Park area. With such a large number it can indicate that the area of the Tesso Nilo National Park area is one of the places that can be used as a displacement of people who do not have sufficient land area to meet their daily needs. Most of the residents around the Tesso Nilo National Park area make a living in agriculture and plantations.

With the increasing population growth around Tesso Nilo National Park, it has reduced the actual land area of Tesso Nilo National Park. Forest destruction caused by forest encroachment has made Tesso Nilo National Park lose its beauty every year. According to The Head of the Lubuk Kembang Bunga Area I Management Section from the TNTN Hall said that there are only about 20,000 hectares of the Tesso Nilo Park area which can be called native forest.

The phenomenon above is actually related to the rapid population growth which tends to form a new bond, namely the extended metopopulation region (EMR) where these changes occupy land without a permit, this is in line with research (Rochaida, 2016)that the impact of environmental damage or community activities is changing its function. land occurs from migratory communities, it is about how they survive in a new place.

According (Sidiq, 2020)the survival strategy for the community is to utilize nature, social capital 
and financial capital without seeing any side effects in the future. A survival strategy that destroys the forest as the lungs of the world should receive good treatment from the people in the environment around the forest so that the forest can function according to its function.

However, the public's concern for forest utilization and forest preservation is decreasing and there are even fewer people who care about forests. This can be seen from the increasing number of illegal loggers (illegal logging), forest encroachers to clear land and entrepreneurs who do not implement the rules and regulations set by the government.

\section{Impact of Migration}

The results of the study found that the migratory residents committed acts of destruction by the encroachers by burning forest areas, which was illegal and against the law because the consequences of what was done by irresponsible individuals in the Tesso Nilo National Park area were very detrimental to many parties, Besides the smoke produced, it will also damage the flora and fauna in the Tesso Nilo forest area.

Thousands of residents from outside Riau, especially from North Sumatra, entered the Tesso Nilo National Park area. They cut down the forest and converted it into an oil palm plantation. The local community members encroach and plant the oil palm because of the large number of oil palm processing companies that exist around Tesso Nilo National Park. The high price of palm oil makes local residents tempted by the benefits they will get and do not pay attention to the preservation of life in the protected forest area.

Apart from the problem of forest destruction that has arisen with the increasing population growth around Tesso Nilo National Park, there are also problems that arise, namely the existence of conflicts that have occurred in Tesso Nilo National Park. As is known, the people living around the Tesso Nilo National Park area consist of several village communities. One of the villages in conflict is Kesuma Village which is directly adjacent to the Tesso Nilo National Park area with a population of various ethnicities, consisting of local (Malay) and immigrant communities from various ethnicities and different backgrounds.

The conditions of the community with different livelihoods and economic backgrounds give their own nuances to life in developing the economy in the agricultural and plantation business in this village. The extent of agricultural land in Kesuma Village makes it attractive for everyone from various regions to migrate to this village with the intention of developing plantation cultivation resulting in the conversion of forest functions into plantation areas (Salim, 1982).

The occurrence of conflict was triggered by differences in viewpoints and interests. In general, conflicts can occur apart from defending ideology as well as a tendency that is oriented towards the economic values of an object. Humans every day do not escape the activities of fulfilling the needs of life by undergoing various activities (Supriatna, 2014).

There are several sources of conflict triggers in the Tesso Nilo National Park area, both internally and externally. Internal conflicts are changes in values and norms that are changed by the circumstances of the community as a result of the process of acculturation in a multicultural society. Meanwhile, the external source of conflict is the change in values and norms that are changed by the circumstances of the community as a result of the direct involvement of institutions as the guardians of values and norms within the community itself. Furthermore, these two sources can trigger conflicts both horizontally and vertically that occur in the Kesuma community.

This relatesacculturation, where culture or contact will lead to a social process between human groups and local culture, not infrequently the cultural elements disappear along with the social process and will cause internal conflict (Indira, Mulyadi, \& Nasrullah, 2019).

The conditions of the people with different livelihoods and economic backgrounds give their own nuances to life in developing the economy in the agricultural and plantation business sectors in this village. The vast agricultural land in Kesuma Village makes it attractive for everyone from various regions to migrate to this village with the intention of developing plantation cultivation resulting in the conversion of forest functions into plantation areas. This is in line with the opinion (Setiawan, 2010) that migration motivation and decisions are determined by driving factors, namely the potential for more promising migration areas for better welfare and vacant lands that can be used for future economic development regardless of the impact of environmental damage.

The conflict between the two classes is inseparable from latent interests, namely the personal interests tucked into these social groups. As in indigenous groups, there are land sellers who deliberately take refuge in Adat organizations for personal gain. Whereas in the domination group that has authority, uncontrolled management creates people who play and are uncontrolled, giving birth to 
people who play and are not serious in carrying out their duties as authority holders. The occurrence of deviations in authority can trigger a conflict whose intentions can become wider if neither party wants to end the conflict.

The impact of forest destruction caused by forest encroachment at the Tesso Nilo National Park which was used as an oil palm plantation area was seen in a hamlet in Lubuk Kembang Bunga Village. Lubuk Kembang Bunga Village is one of the many villages located in the Tesso Nilo National Park area. The hamlet is called Dusun Toro Jaya. Toro Jaya is a hamlet that was only officially in the early 2000s. Now, in almost two decades, around 6,000 to 7,000 families have controlled tens of thousands of hectares of Tesso Nilo National Park. The population spike is an independent census conducted by the Toro Jaya Hamlet to record the population in the hamlet. Toro Jaya is a hamlet that the government admits on the one hand, but does not pay attention to the other.

Apart from plantations owned by the community, there are also oil palm plantations owned by the company. There are about 64 oil palm plantation points owned by investors or cukong in the former HPH concession of PT. Hutani Sola Lestari (HSL). The total area reaches 12,000 hectares while PT. HSL reaches 45,990 hectares. The former concession of PT. Siak Raya Timber (SRT) is now controlled by an oil palm plantation of 14,235 hectares in 36 points of the 38,560 hectare concession area. The core area of Tesso Nilo National Park is controlled by cukong in 150 points with details of more than 44,000 hectares planted with oil palm, 7,000 hectares open, 4,000 hectares of acacia plantations and the remaining 20,000 hectares of natural forest. The area of illegal individual plantations or cukong in Tesso Nilo National Park varies from five hectares to 1,000 hectares.

The most obvious threats to the forest areas of Tesso Nilo National Park are illegal logging and land looting. Illegal logging occurs in almost all areas in the Tesso Nilo National Park. This is due to the economic condition of the community around the forest and the high demand for wood, plus the access to the forest which has been quite smooth with the construction of road corridors in the forest by former concessionaires and large companies such as RAPP. Weak supervision by government agencies in this area also means that logging activities can take place freely.

Looting and land claims are also common in the Tesso Nilo National Park area. The perpetrators of looting and land claims were generally local people whose economic conditions were limited and needed land to expand their gardens and depend on them for their livelihoods. However, it was also found that the outside community committed this violation. The outside community was invited by the village elite who had an interest in controlling the land which in turn would convert the forest into oil palm or rubber plantations. Apart from that, land barons also began to appear with the aim of trading land and making gardens.

The ongoing degradation of the Tesso Nilo National Park forest will also threaten the biodiversity it contains. Habitat loss is a major factor that threatens the preservation of large animals such as elephants and tigers in the area. The reduced habitat has resulted in an increased frequency of conflicts between communities and plantation companies and elephants. Conflicts between communities and tigers have also occurred in recent years. The conflicts that occur usually end with the killing of elephants or tigers which are considered to be disturbing, even though if further investigated then humans are the ones who disturb them.

\section{CONCLUSION}

The results show that the population migration in TNTN has increased significantly, coupled with the birth rate of the population, who are mostly couples of productive age, have made fertile land for population growth in TNTN. The smooth accessibility with the entry of public transportation vehicles (buses) to TNTN, especially Dusun Toro Jaya, coupled with the production of their "oil palm" plantation crops have also become a pull factor for many people to migrate to TNTN. This migration of the population has resulted in forest encroachment into residential areas and oil palm and rubber plantations. The encroachment will have an impact on the destruction and loss of native forest from Tesso Nilo National Park.

\section{REFERENCES}

Danusaputra, M. (1980). Hukum Lingkungan Buku I. Bandung: Binacipta

Dugang, (2013).Konflik Masyarakat Taman Nasional Tesso Nilo (Studi Kasus pada Masyarakat di Desa Kesuma. Jurnal Perencanaan Sosial

Indira, D., Mulyadi, R.M. \& Nasrullah, R. (2019). Komunitas Masyarakat Jawa Di Desa Wanareja Sebagai Jejak Migrasi Masyarakat Jawa Ke Pangandaran. Sosiohumaniora, 21, (1), 34. https://doi.org/10.24198/ sosiohumaniora.v21i1.19024

Ita, D.M. (2014). Migrasi sebagai Bentuk daptasi Perubahan Iklim. Tugas Akhir Mata Kuliah 
Dinamika Kependudukan (Program Studi Sosiologi Pedesaan-Institut Pertanian Bogor.

Rochaida, E. (2016). Dampak Pertumbuhan Penduduk Terhadap Pertumbuhan Ekonomi Dan Keluarga Sejahtera Di Provinsi Kalimantan Timur. Forum Ekonomi, 18, (1), 14-24.

Santoso, A. D. (2018). Dampak Kebijakan Upah Minimum Terhadap Migrasi Internal Di Sulawesi Selatan. Sosiohumaniora, 20, (2), 177-187. https://doi.org/10.24198/ sosiohumaniora.v20i2.11142

Setiawan, I. (2010). Migrasi Penduduk Menuju Daerah Pinggiran Kota Bandung Dan Implikasinya Terhadap Kualitas Lingkungan Permukiman. Jurnal Geografi. 10, (2).

Sidiq, R.S.S. (2020). Strategy Coastal Community Panglima Raja Village. Sosiohumaniora. 22, (3), 281-288. https://doi.org/10.24198/ sosiohumaniora.v22i3.27728

Trendyari, A., \& Yasa, I. (2014). Analisis FaktorFaktor Yang Mempengaruhi Migrasi Masuk Ke Kota Denpasar. E-Jurnal Ekonomi Pembangunan Universitas Udayana, 3, (10), 476-484.
Wilonoyudho, S. (2010). Urbanisasi dan dampak lingkungan di. Manusia Dan Lingkungan. $J$. Manusia dan Lingkungan, 17,(3), 173-182.

Hakim, Abdul. (2005). Pengantar Hukum Kehutanan Indonesia (dalam Era Otonomi Daerah). Bandung: Citra Aditya Bakti

MacKinnon J.M.B Artha. (1982). National Conservation Plan for Indonesia. Bogor (ID): FAO

Mantra, I.B. (2009). Demorafi Umum. Yogyakarta: Pustaka Pelajar Offset

Miles, B.M \& Huberman, A.M. (1994), Qualitative data Analysis: Ashource Book of a New Methods, London, New Delhi.

Salim, E. (1982). Lingkungan Hidup dan Pembangunan. Jakarta: Mutiara

Supriatna J. (2014). Berwisata Alam di Taman Nasional. Jakarta (ID): Yayasan Obor Indonesia

Vinod, T. (2002). The Quality Of Growth:Kualitas Peertumbuhan, Jakarta: Gramedia Pustaka Utama.

WWF. (2013), Sawit Dari Taman Nasional, Menelusuri TBS Sawit Illegal di Riau, Sumatera., Riau. 